\title{
Analysis on German Monetary Policy from 1974 to 1990
}

\author{
Minxu Wang \\ Finance department, Capital University of Economics and Business, Beijing, 100070, China
}

\begin{abstract}
This article analyzes German monetary policy from 1974 to 1990 . During this period, Germany experienced rapid economic growth and maintained the inflation rate at an average low level. This article would like to analyze German monetary policy to find the reasons why Germany could have rapid economic growth and maintain inflation rate at an average low level. Then specific main goal, right choices of monetary policy tools and intermediary indicators, and timely adjustment of the policy were found as the reasons. We also learn some successful experience about monetary policy from Germany and apply them in China.
\end{abstract}

\section{Introduction}

This article chooses period from 1973 to 1990 . In 1973, the Bretton Woods system collapsed and Germany started to adopt floating exchange rate and in 1990, East Germany and West Germany unified which brought big changes to German economics and politics and then to monetary policies. This article analyzes monetary policy including main goal, specific monetary tools and intermediary indicators during this period. And the article draws conclusion about whether these monetary policies in different stage were successful by analyzing whether GDP growth and inflation were improved at the end of every specific period and comparing the results of policy implementation to its target in every stage. The article also focuses on adjustments of monetary policy conducted by Deutsche Bundesbank. By analyzing German monetary policy, the author would like to learn some successful experience about the monetary policy formulation, implementation and adjustment according to different domestic and foreign economic environments

\section{1974-1978: Expansionary monetary policy}

At the beginning of the $70 \mathrm{~s}$, after a long period of economic growth, the Western countries were generally stagnate due to the influence of Keynes's demand management policy. At the same time the war broke out in the Middle East, the price of oil rose sharply. The production costs of factories and enterprises in the western countries increased greatly, and the inflation of goods rose sharply. The inflation rate increased by $16 \%$ in 1974 compared with 1973. In addition, the Bretton Woods system centered on the US dollar collapsed, the fixed exchange rate system no longer existed and
German got back the control of their monetary policy. In response to these changes and German stagflation, Deutsche Bundesbank made its own monetary policy in the following three aspects.

First, the main goal of German monetary policy was to fight against inflation, which was different from most other western countries[1]. According to Phillip Curve, inflation has a negative relationship with unemployment rate. Many countries believed that tolerating and even stimulating limited inflation could lead to greater economic growth and more employment. But the Deutsche Bundesbank Bank insisted the primary goal was to maintain price stability.

Second, Deutsche Bundesbank chose monetary volume growth as the intermediary indicator, which equaled with cash plus bank reserves[2] and Deutsche Bundesbank usually published its monetary volume growth target in December of each year considering the expectation of the potential output growth of the German economy, the maximum tolerance of inflation, and the adjustments that should be made due to the change of velocity of money.

Third, Deutsche Bundesbank mainly used discount rate, Lombard rate and deposit-reserve ratio as tools to implement monetary policies. Usually, discount rate was the lowest rate among the short-term interest rates and German discount policy payed attention to the quota which was calculated based on liable capital of different credit institutions[3]. And during this period, in order to offset the inflation brought by capital over inflow as shown in figure 1 and 2, discount quota was cut down by Deutsche Bundesbank. Besides, Lombard rate was always higher than discount rate and it was always used as emergency financing when bank used out all discount quota[3]. Lombard rate was decreased in this stage and even fell to less than $4 \%$ in 1978 , as shown in figure 3. That means Deutsche Bundesbank made expansionary policy to stimulate economics development. In addition, Deutsche Bundesbank adjusted deposit-reserve ratio to 
change banks' credit expansion capacity. In this stage, Deutsche Bundesbank made different deposit-reserve ratio for residents and non-residents to offset capital inflow. According to Deutsche Bundesbank Act, demand deposit could not exceed $30 \%$, time deposit could not exceed $20 \%$, while Liability reserve ratio ceiling for non-residents was $10 \%[4]$.
The result of monetary policy in this stage was that inflation rate decreased year by year, as shown in figure 4 and GDP growth rate increased and grew by $3 \%$ in 1978 to $4.2 \%$ in 1979 , as shown in figure 5, accompanied by unemployment decreased as shown in figure 6. Stagflation of Germany was improved in this stage.

\section{Foreign direct investment, net inflows (BoP, current US\$) - Germany}

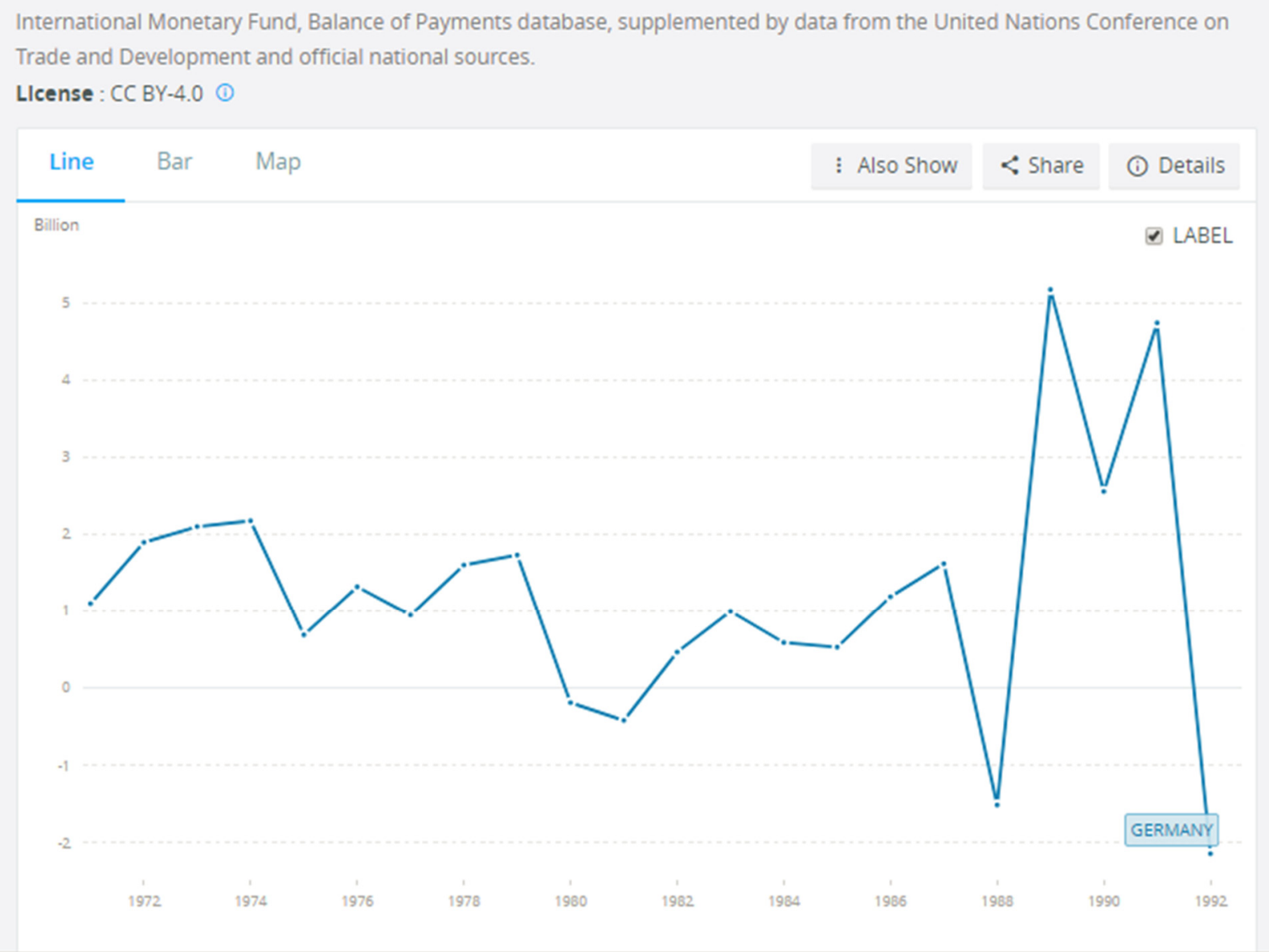

Figure 1. Foreign direct investment to Germany from World Bank Open Data[5] 
Financial account / Net foreign investment in Germany / Portfolio investment / Purchases / Rest of the World DMEURO, million
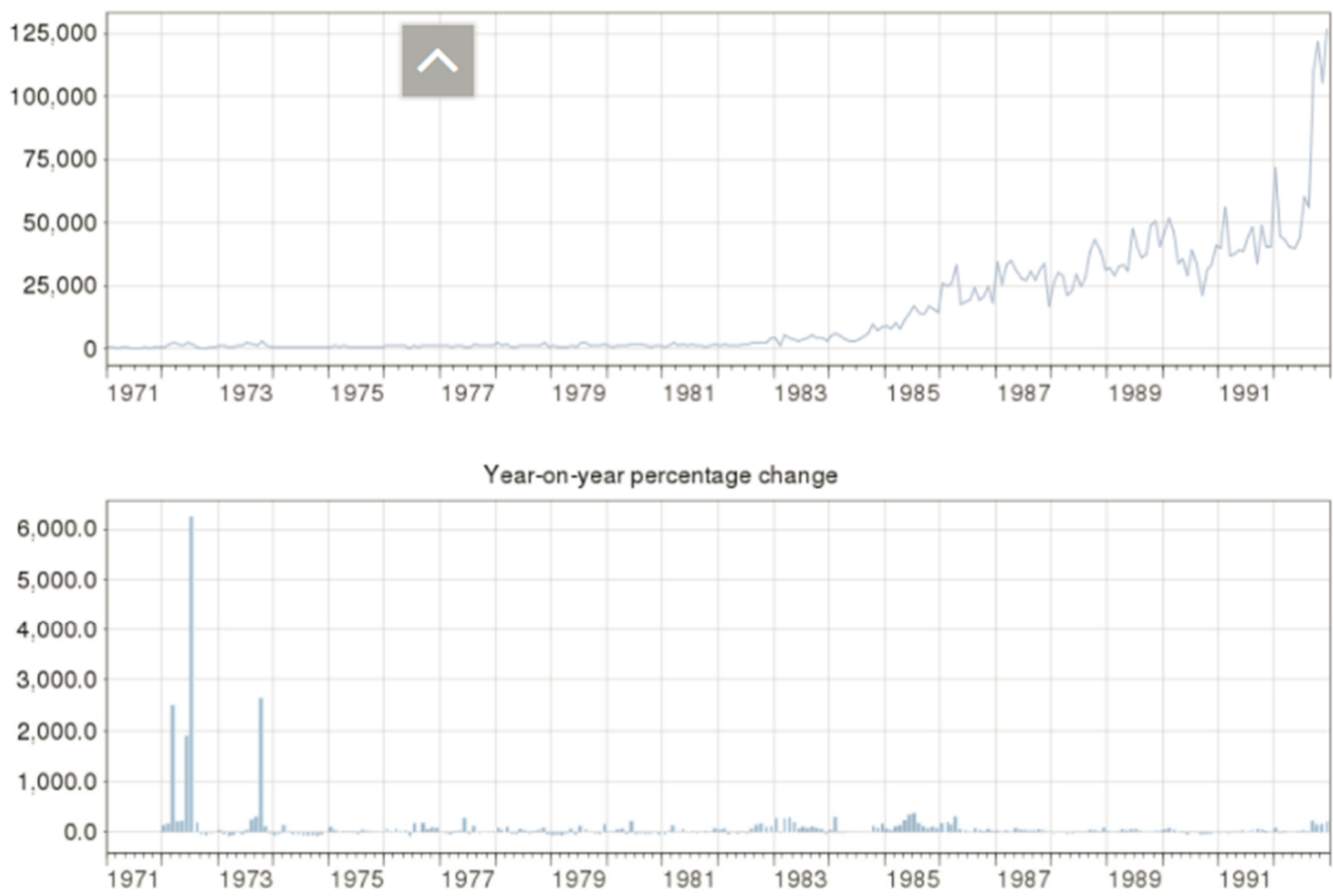

Deutsche Bundesbank

Figure 2. Financial account of Germany from Deutsche Bundesbank Bundesbank[6]
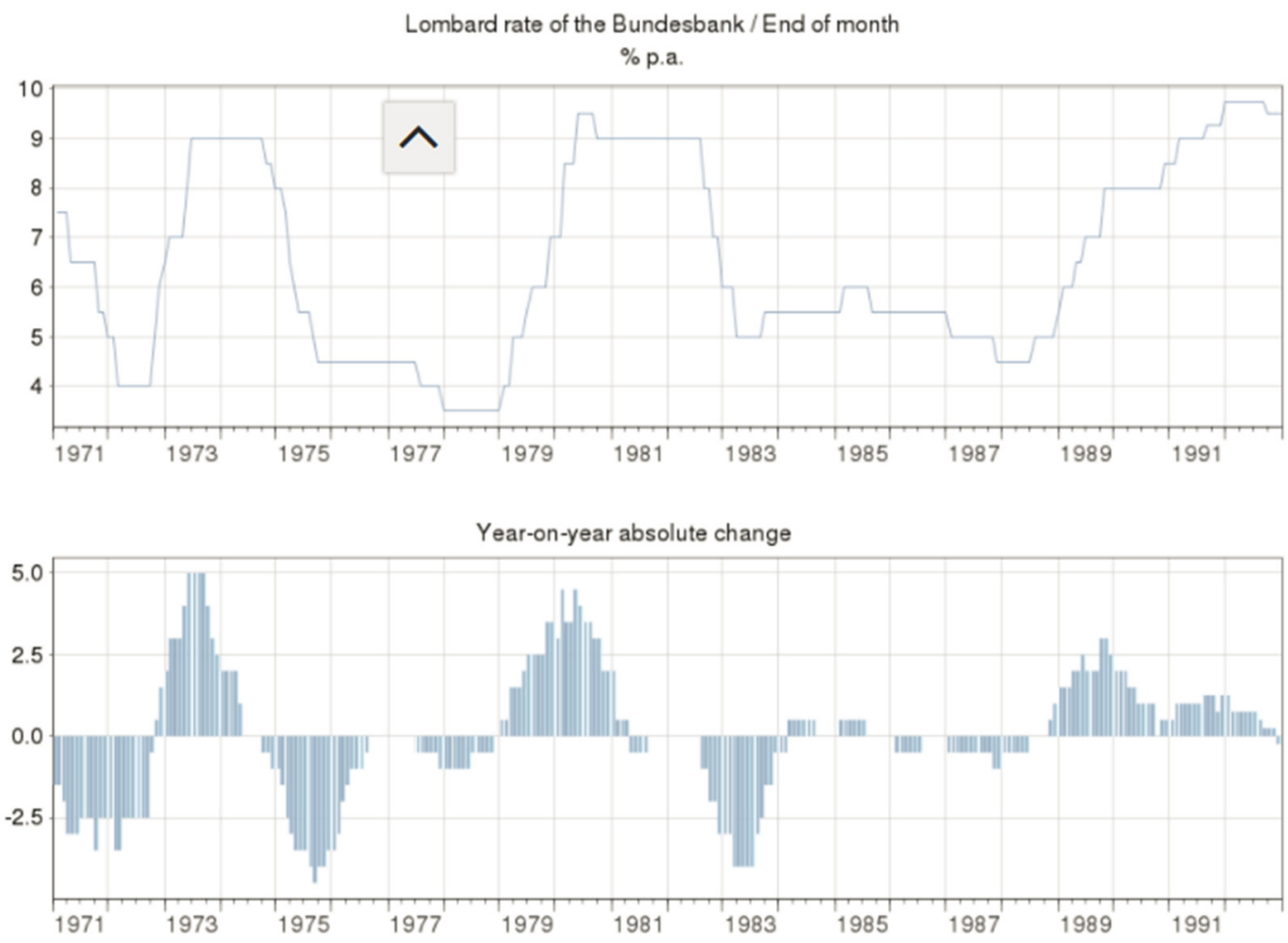

Deutsche Bundesbank

Figure 3. Lombard rate from Deutsche Bundesbank Bundesbank 


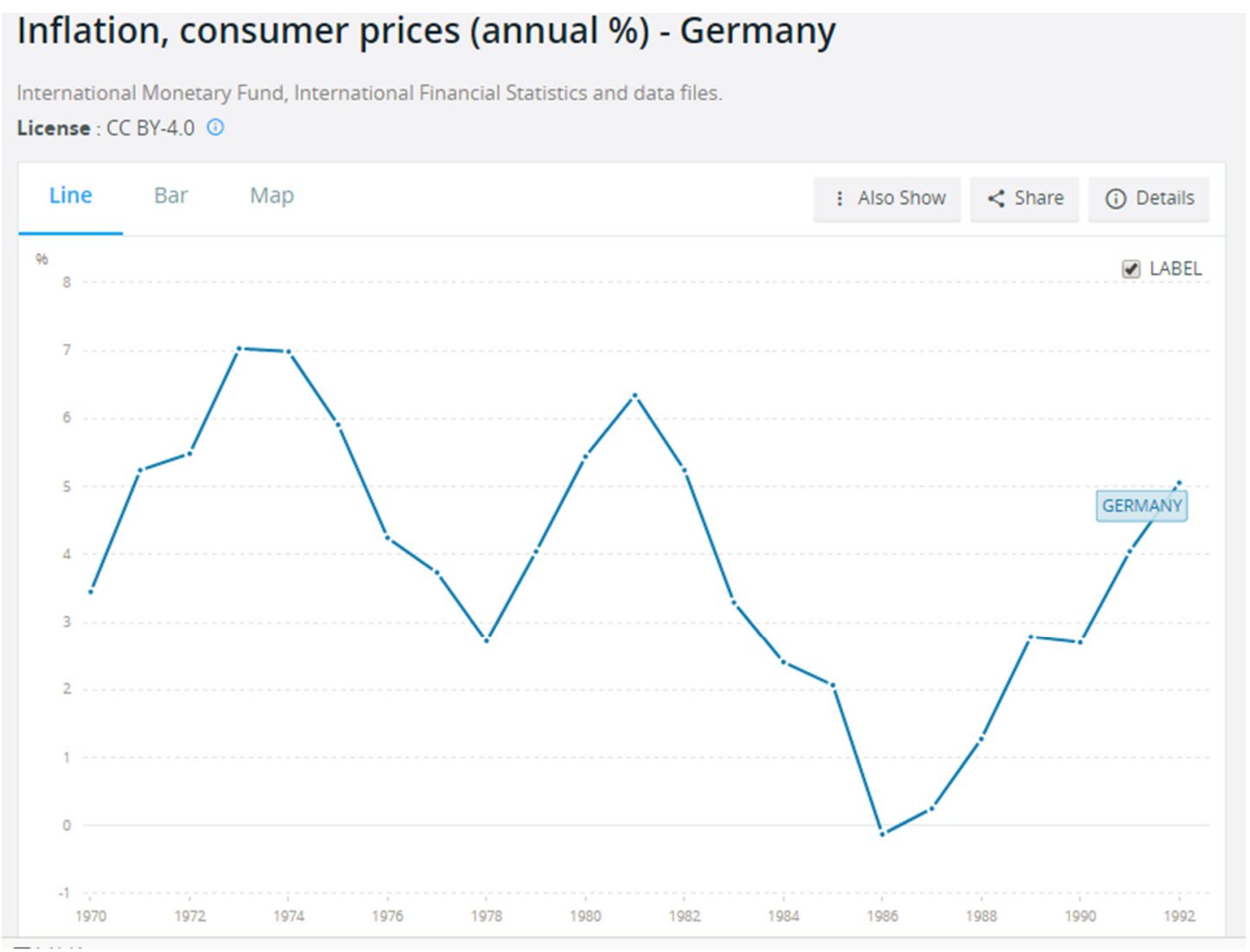

Figure 4. Inflation rate from World Bank Open Data

\section{GDP growth (annual \%) - Germany}

World Bank national accounts data, and OECD National Accounts data files.

License : CC BY-4.0 (1)

\begin{tabular}{l} 
Line Bar Map $\quad$ : Also Show $<$ Share (i) Details \\
\hline$\%$
\end{tabular}

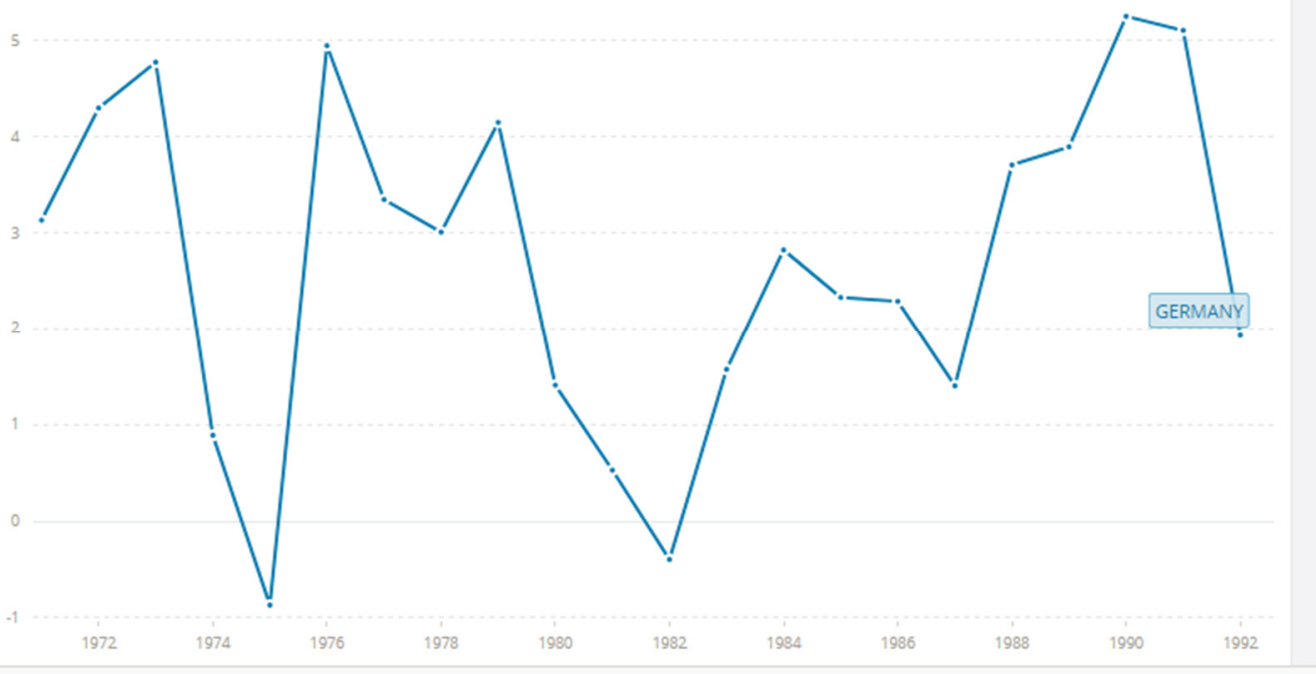

Figure 5. GDP growth rate from World Bank Open Data 


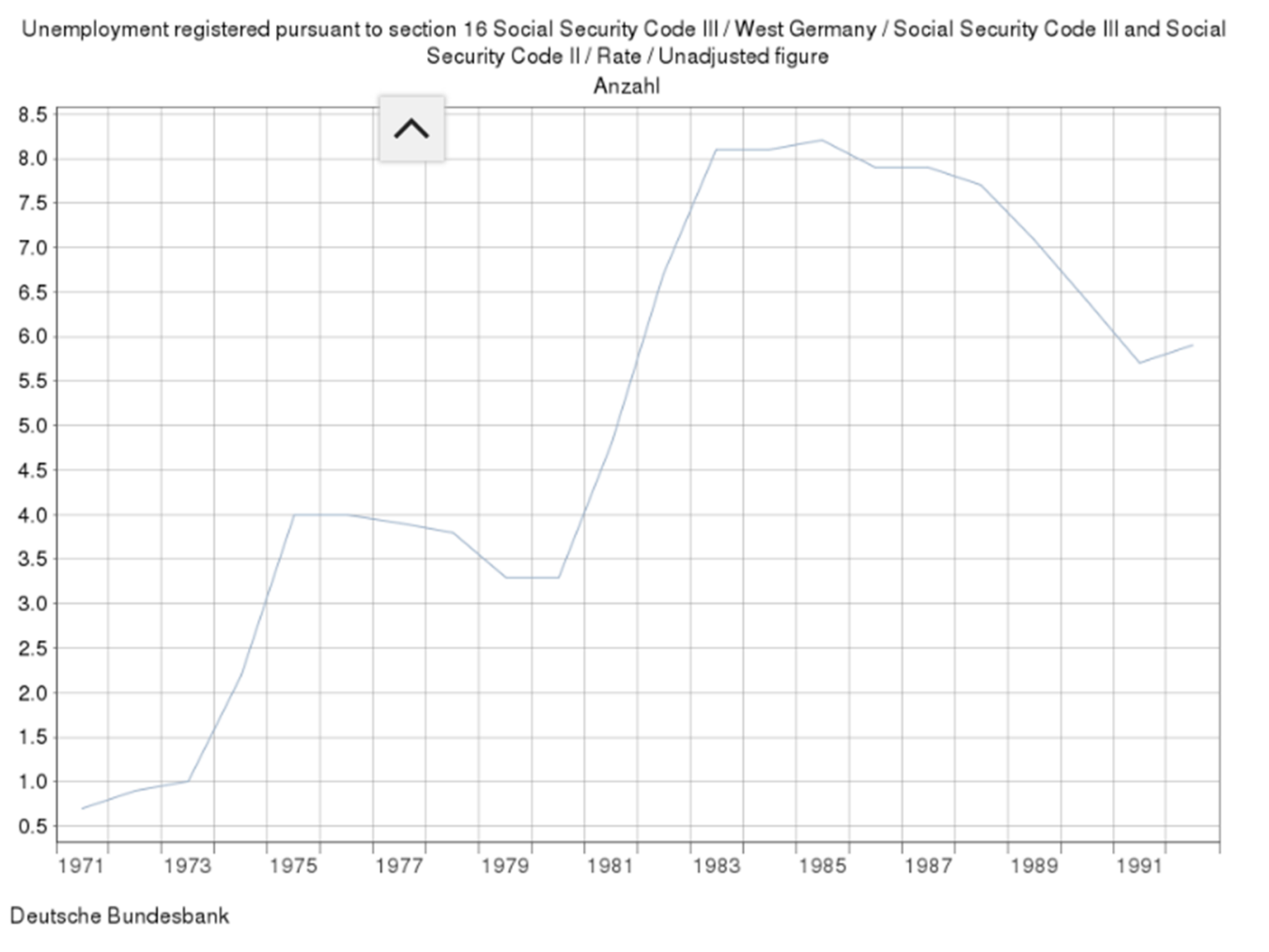

Figure 6. Unemployment rate from Deutsche Bundesbank Bundesbank

\section{1979--1981: Tightening policy.}

Inflation rate was not optimistic in this stage. International oil prices began to soar in 1979, coupled with the previous loose monetary policy, which led to high inflation in Germany. In particular, in 1978, the real monetary growth rate reached $11 \%$, far exceeding the $8 \%$ target set by the Deutsche Bundesbank that yearas shown in table 1. Besides, in August 1980, and the German Mark entered the channel of continuous devaluation, as shown in figure 7 . The change of the exchange rate of the Mark in 1980 was mainly due to the Current Account deficit, as shown in figure 8. The sharp increase in import prices, especially energy prices, led to Germany's Current Account deficit for the first time in 1979, which lasted to 1981 . In early 1979 , due to the inflationary pressure and the Current Account deficit, Deutsche Bundesbank changed its monetary policy and began to implement a tightening monetary policy.

In 1979, Deutsche Bundesbank made two adjustments in monetary volume growth targets. One was to change measurement method----the annual growth rate of the Deutsche Bundesbank's money supply was changed to the fourth quarter of each year to the fourth quarter of the next year. The other one was that the growth target changed from a certain target value to a target range, which gave the bank more flexibility about monetary policy[7].

During this period, in order to fight against inflation, Deutsche Bundesbank decreased their monetary volume growth target, as shown in table 1. Meanwhile, interest rate and discount rate were increased to tight the inflation, as shown in figure 9. Discount rate was raised from $3 \%$ in 1979 to $7 \%$ in 1981 , which increased the cost of loan of commercial bank from Deutsche Bundesbank and then reduced enthusiasm for liquidity. Lombard rate was also increased and showed the same intention of tightening policy. Besides, with more issue of government bonds, Deutsche Bundesbank used open Market operation more frequently then before and bought or sold bonds to influence commercial bank liquidity and then the interest rate[4]. 
Table 1 Monetary targets and their implementation[8]

\begin{tabular}{|c|c|c|c|c|}
\hline \multicolumn{4}{|c|}{ Implementation of MP in } & Germany after 1975 \\
\hline Year & Target & Real growth rate & Whether the target is achieved \\
\hline 1975 & $8 \%$ & $9.50 \%$ & no \\
\hline 1976 & $8 \%$ & $9.20 \%$ & no \\
\hline 1977 & $8 \%$ & $9.00 \%$ & no \\
\hline 1978 & $8 \%$ & $11.40 \%$ & yes \\
\hline 1979 & $6 \%-9 \%$ & $6.40 \%$ & yes \\
\hline 1980 & $5 \%-8 \%$ & $4.80 \%$ & yes \\
\hline 1981 & $4 \%-7 \%$ & $3.50 \%$ & yes \\
\hline 1982 & $4 \%-7 \%$ & $6.00 \%$ & yes \\
\hline 1983 & $4 \%-7 \%$ & $7.00 \%$ & yes \\
\hline 1984 & $4 \%-6 \%$ & $4.70 \%$ & yes \\
\hline 1985 & $3 \%-5 \%$ & $4.50 \%$ & no \\
\hline 1986 & $3.5 \%-5.5 \%$ & $8 \%$ & no \\
\hline 1987 & $3 \%-6 \%$ & $8 \%$ & no \\
\hline 1988 & $3 \%-6 \%$ & $6.70 \%$ & no \\
\hline 1989 & $5 \%$ & $4.60 \%$ & \\
\hline
\end{tabular}

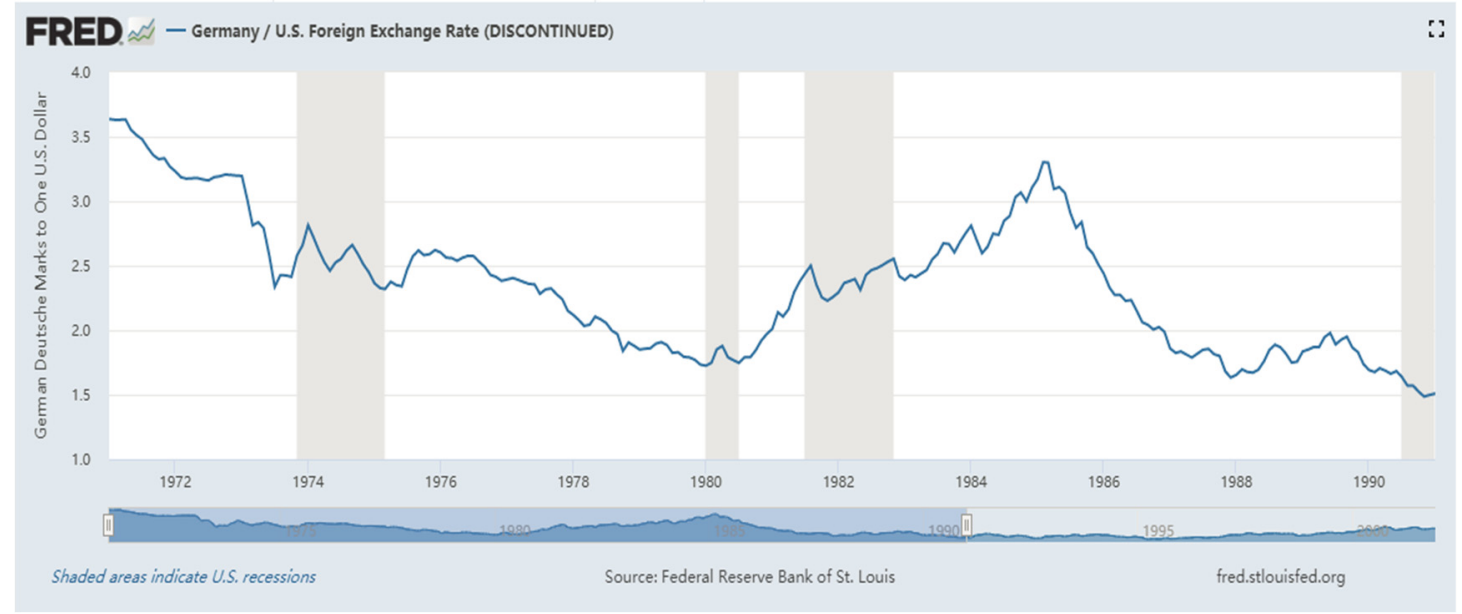

Figure 7. Exchange rate against dollar from fred[9]

FRED $\approx-$ Total Current Account Balance for Germany (DISCONTINUED)

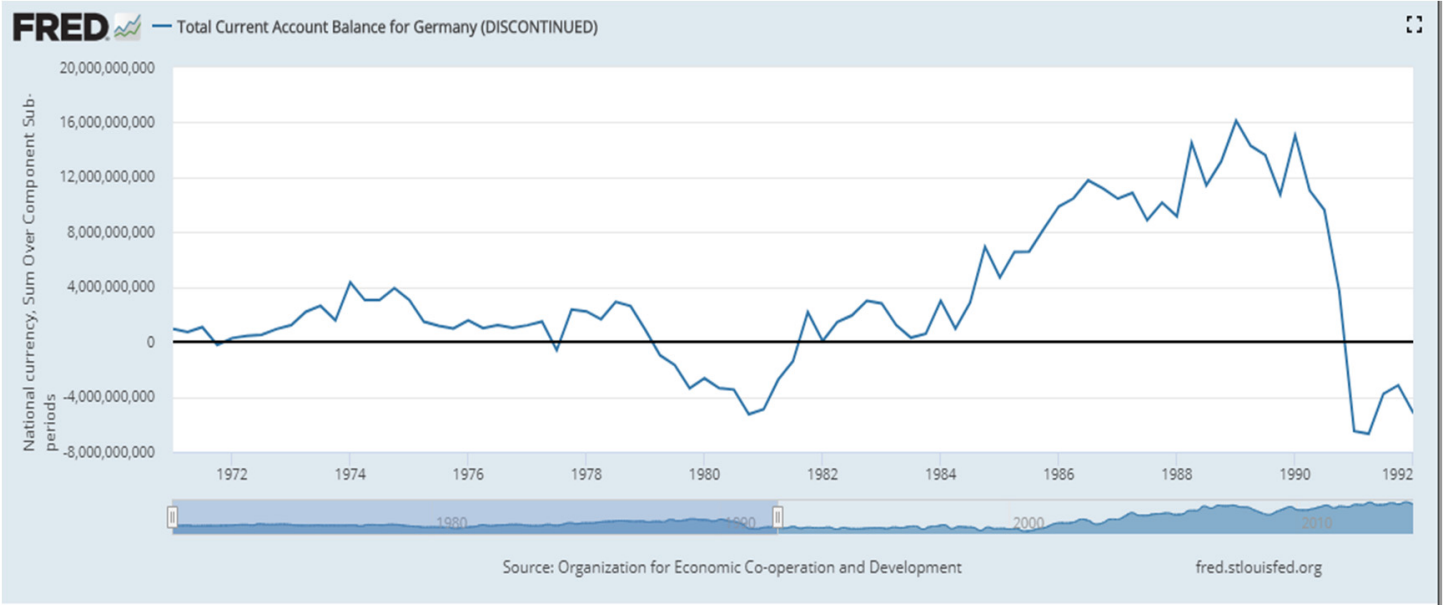

Figure 8. Current account from fred 


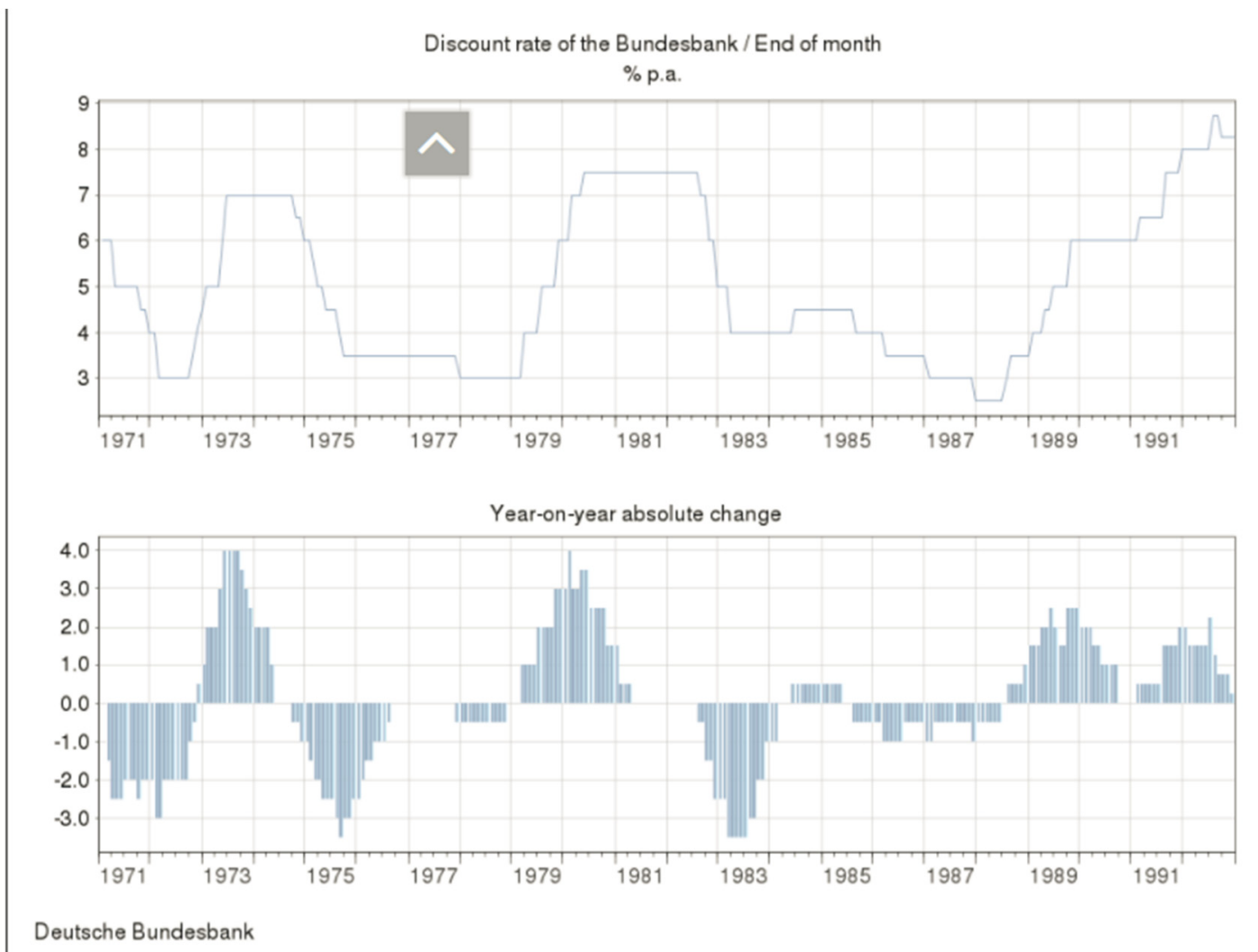

Figure 9. Discount rate from Deutsche Bundesbank Bundesbank

\section{1982--1985: Expansionary monetary policy.}

Tight monetary policy in 1979 led to a fall in inflation and it started to decrease in 1982. The trend of German currency against dollar was the depreciation which helped Germany's current account deficit turned into a surplus in 1982. The exchange rate against dollar was 2.3660 on Feb 1982 and constantly depreciated year by year, and the exchange rate was 3.3025 on Feb 1985. Besides, the energy crisis ended and the weakening domestic economy led to a reduction in import demand. And the weakening domestic economy also helped Germany maintained a Current Account surplus in the following years. At the same time, American economy recession influenced Germany and it led to German economy grow at a lower pace[10] and GDP growth rate in 1982 was even less than zero. The unemployment rate was also pessimistic.

Based on these two backgrounds, Deutsche Bundesbank focused on the growth of economics and took expansionary monetary policy in this stage. Deutsche Bundesbank placed the fight against the devaluation of the Mark at the secondary place, making every effort to promote domestic economic growth[11]. Interest rate and discount rate are at low level to stimulate economics development, as shown in figure 10. As a result, GDP growth rate began to increase from 1983, as shown in figure 5.

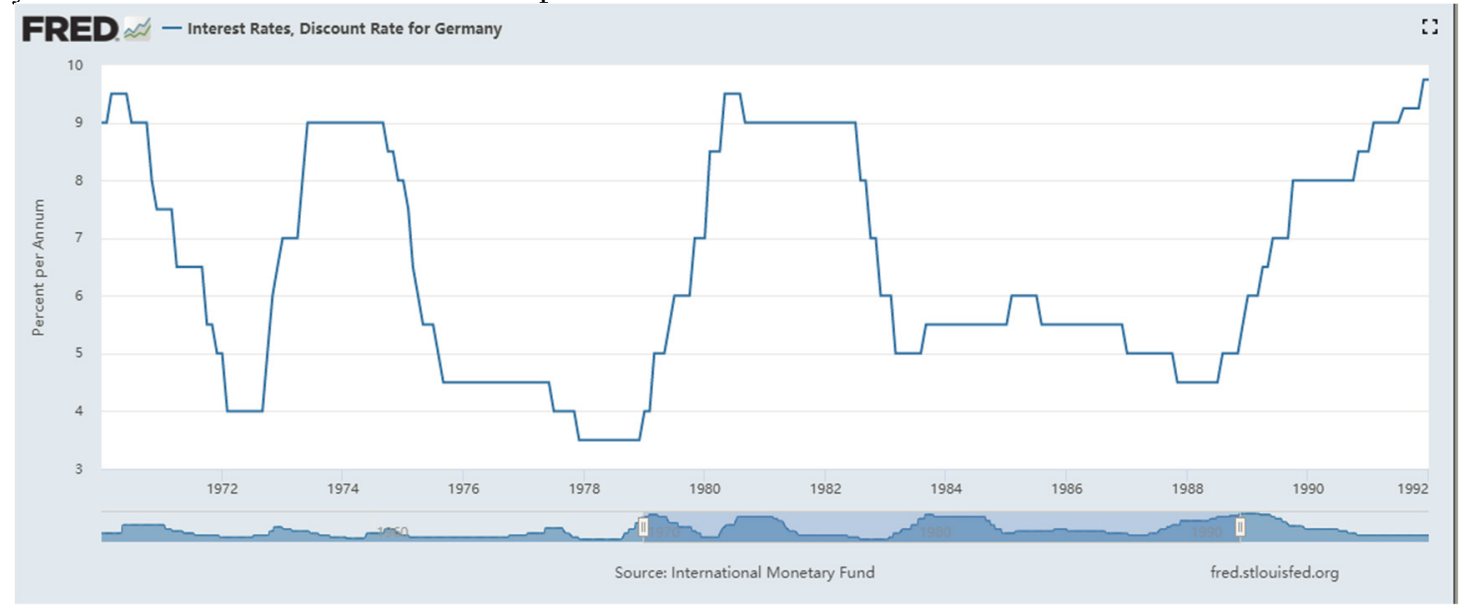

Figure 10. Interest rate, discount rate for Germany from fred 


\section{1986--1990: changed intermediary indicators to $\mathrm{M} 3$}

In 1986, according to table 1 the Deutsche Bundesbank's money volume grew faster than the target range of 2.5 percentage points. Despite this, Deutsche Bundesbank did not raise the official interest rate in this year, which was caused by several factors. During the year, Mark appreciated by $35 \%$ against the US dollar, which reduced the competitiveness of German exports in the international Market and brought pressure on German exports. In addition, the fall in oil prices on the world Market at that time also increased the pressure on Germany's domestic price level. As a result, in 1986, Germany's consumer price index showed a negative growth of $-0.1 \%$, as shown in figure 4 . The decline in price levels, coupled with low growth in output, has encouraged people to hold short-term financial assets, including those in the Deutsche Bundesbank's currency, so that the total amount of money has increased substantially[3]. In the current situation, if the interest rate is raised, the Mark will further appreciate. Further appreciation will hurt the economic growth and further reduce the domestic price level. In 1987, the growth rate of the Deutsche Bundesbank's currency volume once again exceeded the upper limit of the target range, mainly due to excessive bank cash issuance.

Then in 1988, after real growth rate was much larger than target for 2 years, the Deutsche Bundesbank changed the intermediary indicator from the Deutsche Bundesbank money stock to M3. According to Deutsche Bundesbank monthly report[12], Deutsche Bundesbank made the adjustment based on the fact that cash growth was too fast and cash accounted for a large proportion of the Deutsche Bundesbank's currency so that Deutsche Bundesbank money stock tended to exaggerate monetary growth. In long term, the Deutsche Bundesbank's monetary volume and M3 movements were in the same direction. Besides, short-term interest rate only effected M3 structure without effecting M3 total amount[13] and therefore M3 could be the intermediary indicator for monetary policy.

The growth rate of money supply in 1988 still exceeded the target range. There were three reasons for this: first, the lag effect of interest rate fall continued to increase demand for currency; second, the foreign demand for Mark increased significantly; third, the government announced that they would collect withholding income tax. It led investors to withdraw cash from their long-term deposit and these cash naturally expanded the total amount of M3[14].

After the adjustment, Deutsche Bundesbank M3's growth rate in 1989 was about 5\%. Due to the tightening monetary policy implemented by Deutsche Bundesbank at the time and the abolition of the withholding income tax on capital income since July 1, the growth rate of M3 had slowed significantly. During the fourth quarter of 1988 to the fourth quarter of 1989, M3 grew at a rate of 4.6 percent, thus reaching the published about $5 \%$ target.

In 1990, west Germany and east Germany unified which brought some fluctuation to economy. At the same time, Deutsche Bundesbank reiterated to the public that reunification will not change the ultimate goal of monetary policy stabilized by its currency.

\section{Conclusion}

German monetary policies from 1974 to 1990 successfully helped Germany develop economics constantly and maintain inflation rate at an average low level. The clear main goal which was to fight against inflation gave Germany monetary policy a definite direction. The choice of intermediary indicators and adjustment from monetary volume growth to M3 helped Deutsche Bundesbank make specific target in different year. Besides, timely adjustment of monetary policy according to specific economics, inflation and other factors was also important. Meanwhile, right application of different monetary tools helped the policy implement. These all are the reasons why German has rapid economics growth and average low inflation.

\section{ACKNOWLEDGEMENT}

First and foremost, I would like to show my deepest gratitude to my teachers and professors in my university, who have provided me with valuable guidance in every stage of the writing of this thesis. Further, I would like to thank all my friends and roommates for their encouragement and support. Without all their enlightening instruction and impressive kindness, I could not have completed my thesis.

\section{REFERENCES}

1. M. Wei, Y. Liu. Independence and validity test of German monetary policy from 1974 to 1990 [j]. Journal of Beijing Technology and Business University (Social Science Edition), 2013, 28 (01): 101-107.

2. Q. Wang. Economic growth is subject to currency stability: An examination of the Federal German monetary policy and the issue of curbing inflation [J] .China Finance, 1989 (11): 50-52.

3. Y. Feng. On the German monetary policy tool [j]. Economist, 1995 (04): 98-106.

4. Q. Xu, L. Xu. Government Tools and Effects of German Monetary Policy [J] .China Urban Finance, 1995 (06): 47-48.

5. https://data.worldbank.org.cn/

6. https://www.bundesbank.de/

7. Z. Zhu, W. Yang. On the choice of the intermediate goal of German monetary policy since the mid-1970s [j]. World Economy, 1996 (10): 22-25+12.

8. Deutsche Bundesbank Annual Report 1995 page 77.

9. https://fred.stlouisfed.org/ 
10. W. Jiao. Research on the efficiency of monetary policy under open economic conditions [d]. Shanghai Academy of Social Sciences, 2009.

11. M. Wei, X. Liu. Research on German economic policy portfolio under the framework of ternary public opinion and its enlightenment-Taking 1971-1990 as an example [j]. Financial Theory and Practice, 2012(09): 97-102.

12. Deutsche Bundesbank Bundesbank monthly report February 1988, page 9

13. X. Wang, W. Jiang. Objective, Operation and Enlightenment of German Monetary Policy [J] .China Finance, 1997 (06): 36-38.

14. K. Hu. Research on the intermediate target of German monetary policy [j]. German Studies, 1997 (04): 27-31. 